\title{
International migration and turnout bias
}

\author{
Authors: $\underline{\text { Michael J. Wigginton }},{ }^{\dagger 1}$ Daniel Stockemer ${ }^{\dagger 2}$ and Jasmine van Schouwen ${ }^{\dagger 3}$ \\ Affiliation and contact: ${ }^{\dagger}$ School of Political Studies, University of Ottawa, Room FSS7005, 120 \\ University Private, Ottawa ON K1N 6N5 \\ ${ }^{1}$ michael.wigginton@uottawa.ca \\ 2 daniel.stockemer@uottawa.ca \\ 3jasminevanschouwen@hotmail.com
}

Date: May 2019

This is a post-peer-review, pre-copyedit version of an article published in PS: Political Science \& Politics. The final version is available online at: https://doi.org/10.1017/S104909651900101X This version is for private use and may not be distributed further. Please do not cite this version.

\begin{abstract}
Focusing on two commonly used indicators of turnout, VAP turnout (the number of votes cast as a percentage of the population of voting age) and RV turnout (votes cast as a percentage of the number of registered voters), this article discusses possible biases induced by migration flows. Using a global dataset on elections in over 100 democracies between 1990 and 2012, we test the potential bias induced by the percentage of resident non-citizens and nationals living abroad on VAP and RV turnout, respectively. Through time series cross sectional analysis, we find that the number of resident non-citizens does negatively bias VAP turnout, to the extent that a country with 10 percent non-citizen residents would have turnout underreported by nearly 4 percentage points. In contrast, we find that the number of nationals living abroad does not induce a turnout bias.
\end{abstract}

Key Words: VAP turnout, RV turnout, measurement, bias, foreigners, nationals living abroad 


\section{Introduction}

Voting behavior has been a central focus of political science since the behaviorist turn. It is an important indicator for the well-being of democracies (Schumpeter 1976), especially in light of the decline in conventional political participation in democracies since the 1970s (e.g. Blais et al. 2004; Kostelka 2015). In this article, we focus on measurement of electoral participation and the comparability of electoral turnout data. There are two main ways to measure voter turnout; as the number of votes cast as a percentage of either the voting age population (VAP turnout) or the number of registered voters (RV turnout). Most studies on the determinants of political participation do not explicitly discuss their choice or assume that the variation between RV and VAP turnout is negligible (see Geys 2006). Yet, this assumption might be erroneous, as both measures are suboptimal proxies for 'real' turnout. To illustrate the first measure RV turnout might exclude eligible, but unregistered voters, whereas VAP might include ineligible residents such as foreigners.

In this article, we focus on migration flows or more specifically, the number of foreigners living in a country and the number of nationals living abroad. The $21^{\text {st }}$ century has given countries a large number of resident non-citizens and citizens living abroad (Castles, De Haas and Miller 2013). For sure, the turnout literature (e.g. Barreto 2005; Cho 1999) has established that once naturalized these new citizens vote in fewer numbers than natives. Yet, increasing numbers of resident non-citizens and citizens living abroad can also influence the two conventional turnout measures. We hypothesize (1) that large numbers of resident non-citizens influence VAP turnout as this measurement count them as part of the voting age population, despite their ineligibility to vote and (2) that high numbers of nationals living abroad might have an effect on RV turnout, if they are still on electoral lists in their country of origin. We test both hypotheses with the help of descriptive and inferential statistics based on a large-scale global dataset (1990-2012), using RV and VAP turnout figures as the dependent variables, the percentage of foreigners living in the country and the percentage nationals living abroad as the respective independent variables, as well as relevant control variables.

\section{How migration could bias VAP and RV turnout}

Despite some efforts to calculate VEP turnout (see: McDonald and Popkin 2001), RV and VAP turnout remain the dominant dependent variables in turnout studies. For example, the two metaanalyses by Stockemer (2017), as well as Cancela and Geys (2017) find that one of the two indicators is used in the vast majority of studies. While both measures use the same numerator, valid ballots cast, they use different definitions of the population which are vulnerable to different forms of bias, as follows:

$$
\text { RV Turnout }=\frac{\text { Number of votes cast }}{\text { Number of registered voters }} \quad \text { VAP Turnout }=\frac{\text { Number of votes cast }}{\text { Population of voting age }}
$$

Both these sources of bias are quite likely to be exacerbated by migration, as migrants may be erroneously included in the denominator. Because RV turnout defines the population as the number of registered voters, and voter registers are often slow to change, citizens who live abroad could introduce a downward bias if they are still counted in their former electoral district. 
Similarly, as VAP includes all residents of voting age, the presence of ineligible non-citizens could artificially increase the population and deflate measured turnout. Thus, high rates of emigration can cause RV turnout to be underreported, as will high number of immigrants for VAP turnout.

To highlight the first scenario, let us assume a country has 1 million registered voters, 100,000 of whom have left the country (and do not vote) but still appear on electoral lists. If we further assume that 500,000 votes are cast, we would have an officially reported RV turnout figure of 50 percent, but the real turnout figure would be 55.56 percent or 10 percent higher. For VAP, let us instead assume 500,000 votes from a voting age population of 1 million, 100,000 of whom are ineligible non-citizens. Form this we get a VAP turnout again of 50 percent; assuming all citizens were eligible, we can deduct 100,000 from the denominator and get again a real turnout value of 55.56 percent.

Beyond these hypotheticals, both scenarios do play out in the real world. For example, for RV turnout, Hill and Huskey's (2015) study of electoral turnout and labor migration in Kyrgyzstan conclude that differences in migration patterns (one third of Southern households have emigrated, compared to few in the North) have created "missing voters" in the South, thus explaining the turnout disparity, which is in the vicinity of 25 percent between the two regions. Similarly, Pearlman (2014) estimates that 600,000 to 1 million of Lebanon's 3.2 million registered voters reside overseas, and very few of them return home to vote. Furthermore, Kostelka (2015) finds that emigration can explain approximately one-tenth of the approximately $25 \%$ decline in turnout experienced in 10 post-communist countries following democratization. His analysis finds that this includes both an artificial decline, caused by outdated registers, and a real decline, caused by increased costs for emigrants to either return home or go to their embassy to vote. In a VAP example, approximately 25 percent of Israeli residents are non-citizen Palestinians, making VAP turnout grossly under-estimated, as it includes millions of ineligible residents in its denominator (see Norris 2002). In the United States, Macdonald and Popkin (2001) find that including non-citizen residents and ineligible felons caused VAP turnout numbers to be under-estimated by as much as 6 percentage points.

We take these existing case studies as a starting to determine the degree to which the percentage of foreigners bias VAP turnout and how much nationals living abroad bias RV turnout. Is there any systematic effect of migration on either VAP or RV and if so, how can we remedy this effect?

\section{Research Design}

To assess the magnitude of migration's possible bias on reported turnout, we employ measures of VAP and RV turnout retrieved from the International Institute for Democracy and Electoral Assistance (IDEA) (2015) as our two dependent variables. We regress these two dependent variables on the percentage of non-nationals residing in a country and the percentage of nationals living abroad. These regressions will give us an idea of the magnitude of the bias induced by migration flows on turnout. As data for our two migration proxies is not readily available, we calculated them using data on total population size (United Nations' Statistical Division 2016) 
and data the number of resident foreigners/nationals residing abroad (United Nations - Division of Economic and Social Affairs 2015). To have a full model, we also include 8 institutional and socio-demographic control variables commonly used in turnout studies (see Table 1).

For our analysis we have compiled these indicators into a large-scale dataset covering over 500 elections held in democracies between 1990 and 2012. We restrict the date range to the fall of the iron curtain due data availability for migration data (Castles, De Haas and Miller 2013). The restriction to democratic elections is justified on the basis that such elections require transparency as well as the respect of rights to speech and assembly in order to be meaningful (Collier and Vicente 2012). As an inclusion criterion; we use Polity IV rankings and include all country-years of 6 or higher (Marshal et al. 2016). As a result, our data set covers a twenty-twoyear period for established democracies such as Germany or Australia, and a limited period for countries such as Thailand or Mali that moved in and out of the sample of democracies during the time period covered. We could not include data for some tiny countries such as Samoa because of missing data for all or some indicators.

\section{Table 1: Measurement and sourcing of control variables}

\begin{tabular}{|c|c|c|c|}
\hline Indicator & Hypothesis/ Explanation & Measurement & $\begin{array}{l}\text { Data } \\
\text { Source }\end{array}$ \\
\hline $\begin{array}{l}\text { Compulsory } \\
\text { voting }\end{array}$ & $\begin{array}{l}\text { If voting is no longer a democratic right, but a democratic } \\
\text { duty, which is punished for non-compliance, more citizens } \\
\text { should turn out (Singh 2015) }\end{array}$ & $\begin{array}{l}\text { Dummy: } 1 \text { some } \\
\text { punishment for not } \\
\text { voting, } 0 \text { none }\end{array}$ & $\begin{array}{l}\text { IDEA } \\
(2014)\end{array}$ \\
\hline $\begin{array}{l}\text { District } \\
\text { magnitude }\end{array}$ & $\begin{array}{l}\text { The more seats there are to be distributed by district, the } \\
\text { more the electoral results become proportional, and the } \\
\text { higher the chances that 'each' vote counts for the seat } \\
\text { distribution (Stockemer 2015). Large districts also entice } \\
\text { parties to diversify their slates, rendering them more } \\
\text { appealing to various constituencies (Buben \& Kouba 2017) }\end{array}$ & $\begin{array}{l}\text { Weighted district } \\
\text { magnitude }\end{array}$ & $\begin{array}{l}\text { Johnson and } \\
\text { Wallack } \\
\text { (2012) }\end{array}$ \\
\hline $\begin{array}{l}\text { Electoral } \\
\text { closeness }\end{array}$ & $\begin{array}{l}\text { Close elections increase the chances that every vote counts, } \\
\text { they also increase media attraction and campaign activity; all } \\
\text { of which should increase turnout (Arnold 2018) }\end{array}$ & $\begin{array}{l}\text { The percentage- } \\
\text { point gap in votes } \\
\text { between the winner } \\
\text { and runner-up }\end{array}$ & $\begin{array}{l}\text { IDEA } \\
(2015 b)\end{array}$ \\
\hline Presidentialism & $\begin{array}{l}\text { Presidentialism should decrease legislative turnout } \\
\text { considering that the legislative election becomes second } \\
\text { order or less important in a presidential system ( Green \& } \\
\text { Gerber 2015) }\end{array}$ & $\begin{array}{l}\text { Dummy: } 1 \\
\text { presidential system, } \\
0 \text { no presidential } \\
\text { system }\end{array}$ & $\begin{array}{l}\text { IDEA } \\
(2015 a)\end{array}$ \\
\hline Unicameralism & $\begin{array}{l}\text { Unicamerialism should increase voter turnout, as elections } \\
\text { are more decisive (i.e. legislative power is not shared with a } \\
\text { second chamber (Wilford (2017) }\end{array}$ & $\begin{array}{l}\text { Dummy: } 1 \\
\text { unicameral system, } \\
0 \text { no unicameral } \\
\text { system }\end{array}$ & $\begin{array}{l}\text { NationMast } \\
\text { ers (2015) }\end{array}$ \\
\hline
\end{tabular}




\begin{tabular}{|c|c|c|c|}
\hline $\begin{array}{l}\text { Material } \\
\text { Affluence }\end{array}$ & $\begin{array}{l}\text { Material wealth should bring post-materialist values } \\
\text { including the strive for a participatory democracy; this } \\
\text { should include increased turnout (Kasara and Suryanarayam } \\
\text { 2015) }\end{array}$ & $\begin{array}{l}\text { Log GDP per } \\
\text { capita }\end{array}$ & $\begin{array}{l}\text { United } \\
\text { Nations } \\
(2015)\end{array}$ \\
\hline Population size & $\begin{array}{l}\text { Large polities make the political process more anonymous, } \\
\text { decrease contacts between politicians and citizens, and } \\
\text { render the decision making process physically distant for } \\
\text { most citizens; all of which should decrease turnout (Cancela } \\
\text { and Geys 2016) }\end{array}$ & $\begin{array}{l}\text { Log total } \\
\text { population }\end{array}$ & $\begin{array}{l}\text { United } \\
\text { Nations } \\
\text { Statistical } \\
\text { Division } \\
(2015)\end{array}$ \\
\hline OECD member & $\begin{array}{l}\text { This dummy captures the tendency of OECD member states } \\
\text { to have high turnout. }\end{array}$ & $\begin{array}{l}\text { Dummy: } 1 \text { OECD } \\
\text { member (as of } \\
2015), 0 \text { not OECD } \\
\text { member }\end{array}$ & $\begin{array}{l}\text { OECD } \\
(2018)\end{array}$ \\
\hline
\end{tabular}

We use these data for two types of analyses: first, we present some univariate and descriptive statistics, which could already give an indication that some of the turnout decline could be due to measurement error of the two dependent variables. Second, we present the results of a repeated time-series cross sectional regression (i.e. a random effects generalized least squared models (GLS) with clustered standard errors per country (White; 1980; Kmenta 1990). As robustness checks we present three additional models for VAP turnout and RV turnout, respectively. Models 3 and 6 include year dummies; Models 4 and 7 exclude high immigrant/ emigrants countries with more than 40 percent foreigners or national living abroad, respectively; and Models 5 and 8 include year dummies and exclude countries with more than 40 percent foreigners or national living abroad, respectively .

\section{Results}

Our univariate statistics highlight that RV turnout is about 4.7 percentage points higher than VAP turnout, illustrating that the two measures have significant differences (see Table 2). Furthermore, the average percentage of foreigners and nationals living abroad per country is roughly 10 percent. Hence, there is some potential that migration could trigger some bias in our two indicators of electoral participation, in particular in countries with either a lot of immigrants or emigrants.

Table 2: Univariate Statistics

\begin{tabular}{lll}
\hline Variable & Mean & Standard Deviation \\
\hline VAP turnout & 67.21 & 16.35 \\
\hline RV turnout & 71.90 & 15.06 \\
\hline Percent foreigners & 8.65 & 11.47 \\
\hline $\begin{array}{l}\text { Percent nationals living } \\
\text { abroad }\end{array}$ & 11.76 & 13.96 \\
\hline Compulsory voting & .17 & \\
\hline
\end{tabular}




\begin{tabular}{lll}
\hline District Magnitude & 13.08 & 28.56 \\
\hline Electoral Closeness & 13.28 & 13.70 \\
\hline Presidentialism & .24 & .43 \\
\hline Unicameralism & .28 & .45 \\
\hline Log GDP per capita & 8.48 & 1.44 \\
\hline Log population & 15.21 & 2.46 \\
\hline OECD & .40 & .49 \\
\hline
\end{tabular}

If we now look at Figures 1 and 2, which display the relationship between the percentage of foreigners on VAP turnout, and the percentage of nationals living abroad on RV turnout, respectively, we find the expected relationship in the first of the two figures: Figure 1 displays statistically significant and negative line, indicating that VAP turnout is lower if migration is high. In contrast, Figure 2 reveals a rather flat line illustrating that the number of nationals living abroad, if at all, only very moderately influences RV turnout. These graphs, however, only show migration's effect on measured turnout in a bi-variate analysis; for a more precise measure with adequate controls, we employ two multivariate regressions analyses, displayed in Table 2.

Figure 1: The Relationship between the percentage of foreigners living in a country and VAP Turnout

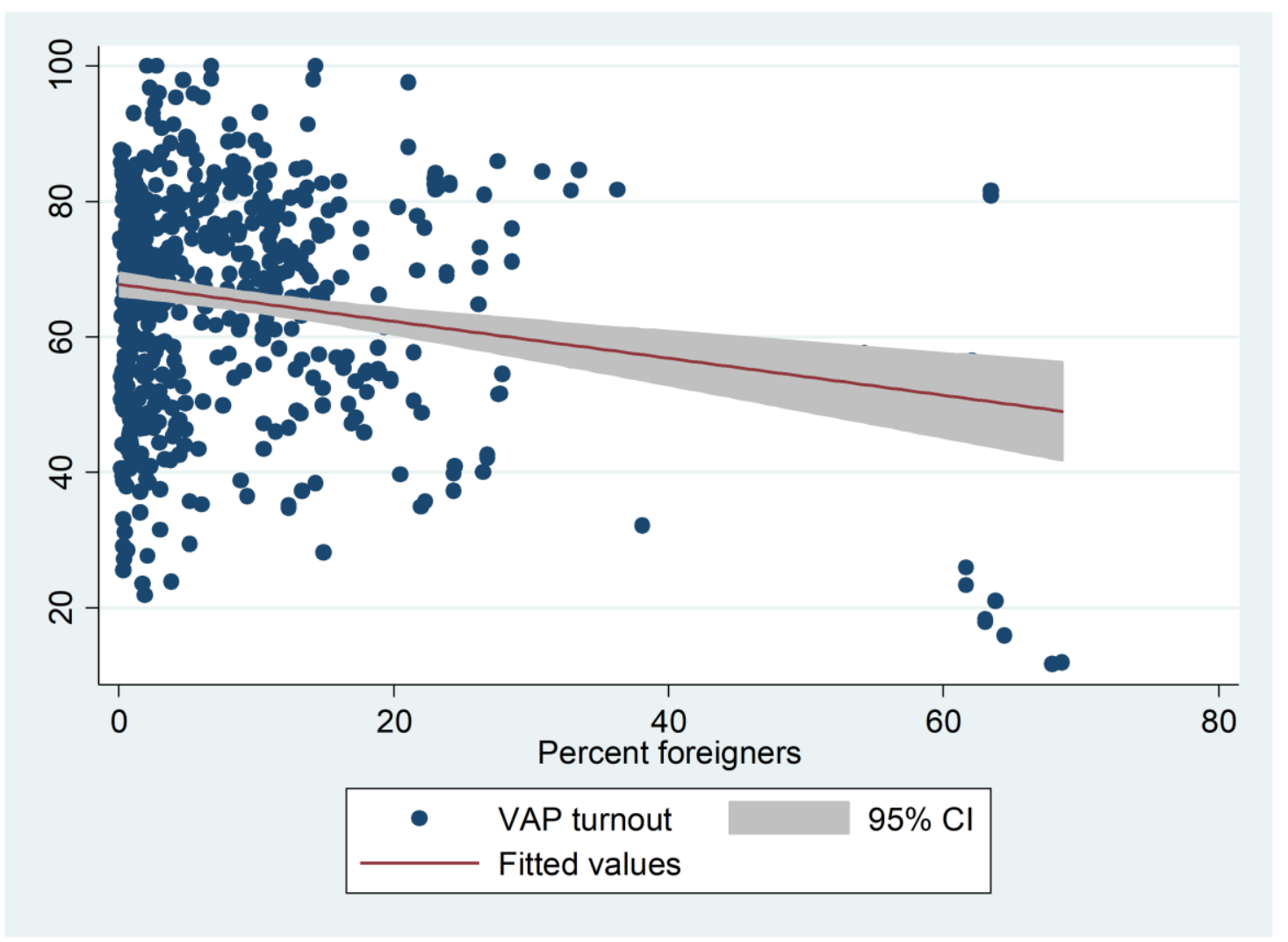


Figure 2: The Relationship between the percentage of nationals living abroad and $R V$

\section{Turnout}

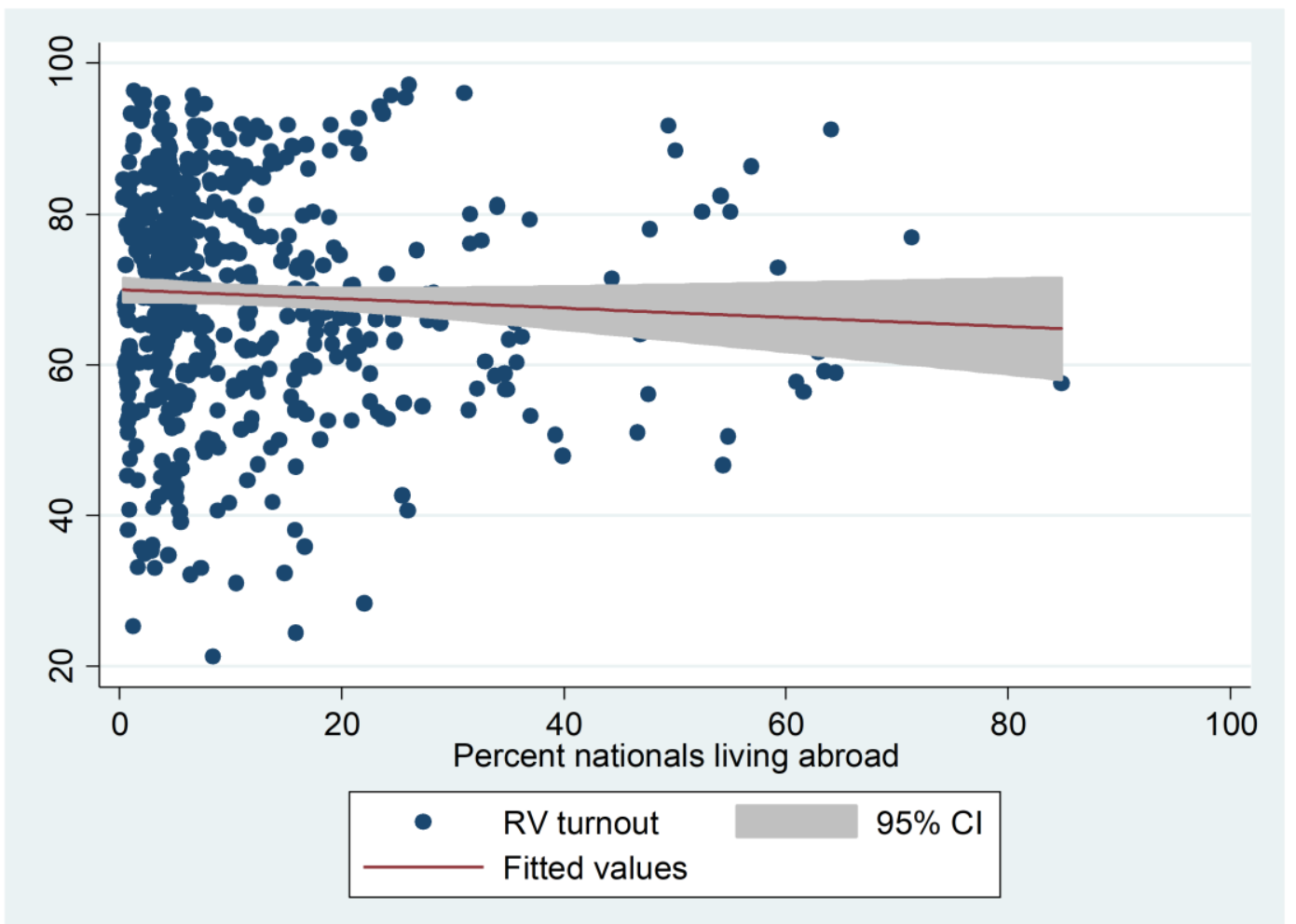

Model 1 seems to confirm the hypothesis that the percentage of foreigners negatively influences VAP turnout, with the regression weight substantively predicting that VAP turnout decreases by .5 percentage points for every 1 percentage point of non-national residents in the respective country. This implies that the reported VAP turnout would be 5 percentage points lower than the actual turnout rate, if we have 10 percent foreigners in a country. ${ }^{1}$ This relationship is robust with the introduction of year dummies (see Model 3 in the Appendix). Yet, Figure 2 illustrates that there are potentially several influential points or outliers (i.e. countries with more than 40 percent immigrants), which could potentially drive this link between percent foreigners and VAP turnout. To test the degree to which this is the case, we exclude all country years with 40 or more percent foreigners (see Models 4 and 5 in the Appendix). ${ }^{2}$ The results are relatively robust. The regression coefficient of the predictor percent foreigners is still statistically significant at the 10 percent level and of moderate strength (i.e. the unstandardized coefficient in the model with year dummies is -.428 and in the model with year dummies and the exclusion of countries with more than 40 percent foreigners it is -.372).

\footnotetext{
${ }^{1}$ In percent, the drop is even larger. To highlight, let us assume that a country has an official VAP turnout rate of 60 percent. Model 1 estimates that this turnout rate is by 5 percentage points inflated, and should only be around 55 , which equates to nearly a more than 8 percent drop.

2 The countries with more than 40 percent foreigners are: Andorra $(1993 ; 1997 ; 2001 ; 2005 ; 2009 ; 2011)$, Liechtenstein (1993; 1994; 1997; 2001; 2005; 2009); Luxembourg (2009), Monaco (1993; 1998; 2003; 2008). Other non-democracies, which are not part of our model with more than 40 percent foreigners are: Bahrain, Jordan, and Kuwait
} 
In contrast, Model 2 indicates that the relationship between the percentage of nationals living abroad and RV turnout is small, with the regression coefficient only statistically significant at the 10 percent level and predicting a negligible 1.6 percentage point's drop per 10 percentage points of nationals living abroad. The robustness checks in Table 5 generally confirm this small association. This lets us conclude that while some specific countries, such as some Eastern European countries (e.g. Macedonia and Poland), may have RV turnout biased by high numbers of nationals living abroad still being on the electoral lists, this is probably not a general trend and most countries appear to be accurately removing from their electoral lists those non-resident citizens who do not specifically register. Yet, what the main model also reports that at the percent foreigners seems to have a small positive association on RV turnout. The robustness checks in Table 5 seem to confirm this tendency.

Table 3: Regression analyses measuring the influence of migration flows on turnout ${ }^{3}$

\begin{tabular}{lllll}
\hline & \multicolumn{2}{l}{ Model 1 (VAP turnout) } & \multicolumn{2}{l}{ Model 2 (RV turnout) } \\
\hline Percent foreigners & $-.503^{* * *}$ & $(.159)$ & $.227^{* *}$ & $(.081)$ \\
\hline Percent nationals living abroad & .031 & $(.085)$ & $-.161^{*}$ & $(.086)$ \\
\hline Compulsory voting & $10.29 * * *$ & $(3.35)$ & $15.71^{* * *}$ & $(3.07)$ \\
\hline District Magnitude & .013 & $(.049)$ & .025 & $(.047)$ \\
\hline Electoral Closeness & $-.139 * * *$ & $(.038)$ & -.044 & $(.043)$ \\
\hline Presidentialism & -3.39 & $(3.27)$ & -1.61 & $(3.27)$ \\
\hline Unicameralism & $4.86^{* * *}$ & $(1.83)$ & $3.21 * *$ & $(1.61)$ \\
\hline Log GDP per capita & -.767 & $(.1 .24)$ & $-.3 .24 * * *$ & $(1.02)$ \\
\hline Log population & $-2.42^{* *}$ & $(.725)$ & $-2.77 * * *$ & $(.658)$ \\
\hline OECD & $8.30 *$ & $(4.51)$ & $9.60 * * *$ & $(3.70)$ \\
\hline Constant & $108.95^{* * *}$ & $(15.21)$ & $133.75^{* * *}$ & $(12.58)$ \\
\hline Rsquared & .26 & & .22 & \\
\hline $\mathbf{N}($ observations) & 514 & & 514 & \\
\hline $\mathbf{N}$ (countries & 109 & & 109 & \\
\hline
\end{tabular}

\section{Discussion}

So how should we measure turnout in our models on electoral participation? The first question authors must ask themselves is which indicator they should use. Both indicators have their problems. If scholars opt for the VAP turnout measure, they might not get comparable data if comparing countries with few and with foreigners. For example, based on the results of this study, a country with 20 percent foreigners could underestimate VAP by up to 10 percentage points, compared to a country with no foreigners. At the least scholars should control for this bias. One way is to add the percentage of foreigners in the voting age population on the right hand side in each model. This should give scholars an indication of the bias induced by foreigners

\footnotetext{
${ }^{3}$ The results of models 1 and 2 are robust with the inclusion of a time trend coded 0 for 1990 and 22 for 2012. 
in turnout models, which they could then control for in subsequent analysis. Alternatively, researchers could calculate an approximation of VEP turnout. To do so, they could deduct the number of non-nationals at voting age from the voting age population to provide a better estimate of the voting eligible population. ${ }^{4}$

If researchers opt for the RV turnout measure, there is less biased induced by immigration and emigration and the deviations induced by foreigners or non-nationals abroad are only minor. This does not exclude that for countries with a lot of expatriates such as Lebanon or Macedonia, emigration cannot influence turnout, but overall this impact is limited. However, this does not mean that the RV turnout measure is without problems; it treats countries with automatic voter registration such as Germany similarly to countries with voluntary registration such as the US and the Bahamas (e.g. in the Bahamas around 20 percent of eligible voters are not registered (Brennen Center 2013)). Hence, such a measure should at least control for the number of eligible voters, who are not on electoral lists in countries where voter registration is not automatic.

\section{Conclusion}

In this research note we have focused on the measurement of turnout. We have shown that international migration flows can change the measurement of turnout by introducing a significant bias into commonly used measures of turnout. While the bias of non-resident citizens on RV turnout is tiny in all but a few cases, the influence of resident non-citizens on VAP turnout can be large enough to substantively affect the reported turnout figure in democracies. Given this bias, the rare availability of VEP turnout figures, and the limitations of RV turnout in comparisons across countries, we suggest one solution to the turnout measurement problem. We suggest to use in the denominator the voting age population less the number of non-citizens of voting age. Using this approximation of the percentage of eligible voters as a proxy for turnout, which, in similar form, has been calculated in one country studies focusing on the US (Wattenberg 2005; Holbrook and Heidbreder 2010), would be a better approximation for turnout.

Finally a word of caution is in order. For sure, foreigners are a real source of bias for VAP turnout. The same might not be true for nationals living abroad. Only if they are not removed from electoral lists at home they might be a real source of bias. However, if they are removed from the list and decide to register in their foreign embassy, they might face higher costs to vote, but they should still count as registered voters. Unfortunately, the current data does not allow us disentangle these intricacies. This alone calls for renewed research on how we measure our core variable in political behavior, turnout. Nevertheless, we have shown that the measurement of electoral participation is tricky and can induce a considerable amount of bias in the operationalization of turnout.

\footnotetext{
${ }^{4}$ Granted, groups of citizens who are not eligible to vote such as prison inmates and the those deemed mentally incapable in some US states, could still slightly bias this 'new' indicator of electoral participation, although this bias would be infinitively smaller than that experienced by VAP today
} 


\section{Appendix: Robustness checks}

Table 4: Additional specifications (Model 3 = VAP model with year dummies; Model $4=$ VAP model excluding countries with more than 40 percent foreigners; Model $5=$ VAP model with year dummies and excluding countries with more than 40 percent foreigners)

\begin{tabular}{llll}
\hline & Model 3 & Model 4 & Model 5 \\
\hline Percent foreigners & $-.473 * * *(.159)$ & $-.428 *(.225)$ & $-.372 *(.219)$ \\
\hline Percent nationals living abroad & $.085(.095)$ & $.083(.107)$ & $.153(.113)$ \\
\hline Compulsory voting & $9.07 * * *(3.48)$ & $9.95 * * *(3.32)$ & $8.71 * *(3.46)$ \\
\hline District Magnitude & $.019(.048)$ & $.010(.049)$ & $.016(.048)$ \\
\hline Electoral Closeness & $-.159 * * *(.040)$ & $-.125 * * *(.038)$ & $-.141 * * *(.039)$ \\
\hline Presidentialism & $-2.17(3.39)$ & $-3.13(3.32)$ & $-1.72(3.44)$ \\
\hline Unicameralism & $5.44 * * * 1.92)$ & $4.70 * * *(1.73)$ & $5.21 * * *(1.84)$ \\
\hline Log GDP per capita & $.586(1.30)$ & $-.578 * * *(1.23)$ & $.878(1.31)$ \\
\hline Log population & $-1.71 * *(.778)$ & $-2.23 * * *(.757)$ & $-1.51 *(.808)$ \\
\hline OECD & $4.93(4.49)$ & $7.56(4.49)$ & $4.13(4.46)$ \\
\hline Constant & $86.84 * * *(16.45)$ & $103.54 * * *(15.03)$ & $80.33 * * *(16.81)$ \\
\hline Rsquared & .28 & .21 & .24 \\
\hline N (observations) & 514 & 499 & 499 \\
\hline N (countries & 109 & 106 & 106
\end{tabular}

Standard errors in parentheses, $* p<.10, * * p<.05, * * * p<.01$ (two tailed).

Table 5: Additional specifications (Model $6=\mathrm{RV}$ model with year dummies; Model $7=\mathrm{RV}$ model excluding countries with more than 40 percent nationals living abroad; Model $8=\mathrm{RV}$ model with year dummies and excluding countries with more than 40 percent nationals living abroad)

\begin{tabular}{llll}
\hline & Model 6 & Model 7 & Model 8 \\
\hline Percent foreigners & $.224^{* *}(.093)$ & $.183^{* *}(.092)$ & $.200^{* *}(.091)$ \\
\hline Percent nationals living abroad & $-.105(.079)$ & $-.317^{* * *}(.115)$ & $-.245^{* *}(.107)$ \\
\hline Compulsory voting & $14.29 * * *(3.00)$ & $15.70^{* * *(3.07)}$ & $14.13 * * *(3.00)$ \\
\hline District Magnitude & $.034(.045)$ & $.020(.045)$ & $.024(.043)$ \\
\hline Electoral Closeness & $-.063(.043)$ & $-.038(.044)$ & $-.058(.043)$ \\
\hline Presidentialism & $-.078(3.34)$ & $-2.17(3.34)$ & $-.721(3.44)$ \\
\hline Unicameralism & $3.92 * * *(1.73)$ & $3.47 * *(1.64)$ & $4.22 * *(1.78)$ \\
\hline Log GDP per capita & $-.798(1.11)$ & $3.25 * * *(1.01)$ & $-.886(1.11)$ \\
\hline Log population & $-1.84 * *(.670)$ & $-3.17 * * *(.681)$ & $-2.17 * * *(.703)$ \\
\hline OECD & $4.35(3.45)$ & $9.5 * *(3.75)$ & $4.25(3.51)$ \\
\hline Constant & $103.74 * * *(14.05)$ & $141.90 * * *(13.23)$ & $111.32 * * *(15.04)$ \\
\hline Rsquared & .27 & .23 & .29 \\
\hline $\mathbf{N}($ observations) & 514 & 493 & 493 \\
\hline $\mathbf{N}($ countries & 109 & 106 & 106
\end{tabular}

Standard errors in parentheses, ${ }^{*} \mathrm{p}<.10,{ }^{*} \mathrm{p}<.05, * * * \mathrm{p}<.01$ (two tailed). 


\section{References:}

Arnold, F. (2018). Turnout and closeness: evidence from 60 years of Bavarian mayoral elections. The Scandinavian Journal of Economics, 120(2), 624-653.

Barreto, Matt A. 2005. 'Latino Immigrants at the Polls: Foreign-Born Voter Turnout in the 2002 Election'. Political Research Quarterly 58 (1): 79-86.

Blais, André. 2006. 'What Affects Voter Turnout?' Annual Review of Political Science 9 (1): 111-25. Blais, André, Elisabeth Gidengil, and Neil Nevitte. 2004. 'Where Does Turnout Decline Come From?' European Journal of Political Research 43 (2): 221-36.

Brennen Center. 2013. 'Appendix Bahamas'. 2013. http://www.brennancenter.org/sites/default/files/legacy/publications/Appendix.Bahamas.pdf.

Buben, R., \& Kouba, K. (2017). Proportional Representation, Large District Magnitude and Closed Lists. World Political Science, 13(2), 151-191.

Cancela, João, and Benny Geys. 2016. 'Explaining Voter Turnout: A Meta-Analysis of National and Subnational Elections'. Electoral Studies 42: 264-275.

Castles, Stephen, Hein De Haas, and Mark J. Miller. 2013. The Age of Migration: International Population Movements in the Modern World. Palgrave Macmillan.

Cho, Wendy K. Tam. 1999. 'Naturalization, Socialization, Participation: Immigrants and (Non-) Voting'. The Journal of Politics 61 (04): 1140-1155.

Collier, Paul, and Pedro C. Vicente. 2012. 'Violence, Bribery, and Fraud: The Political Economy of Elections in Sub-Saharan Africa'. Public Choice 153 (1-2): 117-147.

Geys, Benny. 2006. 'Explaining Voter Turnout: A Review of Aggregate-Level Research'. Electoral Studies 25 (4): 637-663.

Green, D. P., \& Gerber, A. S. (2015). Get out the vote: How to increase voter turnout. New York: Brookings Institution Press.

Hill, David, and Eugene Huskey. 2015. 'Electoral Stakes, Labor Migration, and Voter Turnout: The 2011 Presidential Election in Kyrgyzstan'. Demokratizatsiya: The Journal of Post-Soviet Democratization 23 (1): 3-30.

Holbrook, Thomas, and Brianne Heidbreder. 2010. 'Does Measurement Matter? The Case of VAP and VEP in Models of Voter Turnout in the United States'. State Politics \& Policy Quarterly 10 (2): $157-179$.

International Institute for Democracy and Electoral Assistance (IDEA). 2014. 'Compulsory Voting'. 2014. http://www.idea.int/vt/compulsory_voting.cfm.

—. 2015a. 'Parliamentary Elections'. 2015. http://www.idea.int/vt/country_view.cfm? CountryCode $=$ PW.

2015b. 'Voter Turnout'. 2015. http://www.idea.int/vt/index.cfm.

Johnson, Joel W., and Jessica S. Wallack. 2012. 'Electoral Systems and the Personal Vote'. https://hdl.handle.net/1902.1/17901.

Kasara, K., \& Suryanarayan, P. (2015). When do the rich vote less than the poor and why? Explaining turnout inequality across the world. American Journal of Political Science, 59(3), 613-627.

Kmenta, Jan. 1990. Elements of Econometrics. London: Collier Macmillan. 
Kostelka, Filip. 2015. 'To Mobilise and Demobilise: The Puzzling Decline of Voter Turnout in PostCommunist Democracies'. PhD Thesis, Paris, Institut d'études politiques.

Marshall, Monty G., Ted Robert Gurr, and Keith Jaggers. 2016. 'Polity IV Project: Political Regime Characteristics and Transitions, 1800-2016'. Center for Systemic Peace. http://www.systemicpeace.org/inscrdata.html.

McDonald, Michael P., and Samuel L. Popkin. 2001. 'The Myth of the Vanishing Voter'. American Political Science Review 95 (4): 963-974.

NationMaster. 2015. 'Countries Compared by Government > Legislative Branch. International Statistics at NationMaster.Com'. Accessed 12 November 2015. http://www.nationmaster.com/country-info/stats/Government/Legislative-branch.

Norris, Pippa. 2002. Rising Phoenix: Democratic Participation Worldwide. Cambridge: Cambridge University Press.

Organisation for Economic Co-operation and Development. 2018. 'List of OECD Member Countries Ratification of the Convention on the OECD - OECD'. OECD.Org. 2018. http://www.oecd.org/about/membersandpartners/list-oecd-member-countries.htm.

Pearlman, Wendy. 2014. 'Competing for Lebanon's Diaspora: Transnationalism and Domestic Struggles in a Weak State'. International Migration Review 48 (1): 34-75.

Schumpeter, Joseph A. 1976. Capitalism, Socialism and Democracy. London: Allen \& Unwin.

Singh, S. P. (2015). Compulsory voting and the turnout decision calculus. Political Studies, 63(3), 548-568.

Stockemer, Daniel. 2017. 'What Affects Voter Turnout? A Review Article/Meta-Analysis of Aggregate Research'. Government and Opposition 52 (4): 698-722.

Stockemer, D. (2015). District magnitude and electoral turnout: A macro-level global analysis. Acta Politica, 50(1), 82-100.

United Nations. 2015. 'UN Data: Per Capita GDP at Current Prices'. 2015. http://data.un.org/Data.aspx?q=GDP+per+capita\&d=SNAAMA\&f=grID \%3a101 \%3bcurrIDUS\%3bpcFlag\%3a1.

United Nations - Division of Economic and Social Affairs. 2015. 'International Migrant Stock Total'. 2015. http://www.un.org/en/development/desa/ population/migration/data/index.shtml.

United Nations Statistical Division. 2016. 'Population and Vital Statistics Report'. 2016. http://unstats.un.org/unsd/demographic/products/vitstats/default.htm.

Wattenberg, Martin P. 2005. 'Elections: Turnout in the 2004 Presidential Election'. Presidential Studies Quarterly 35 (1): 138-46.

White, Halbert. 1980. 'A Heteroskedasticity-Consistent Covariance Matrix Estimator and a Direct Test for Heteroskedasticity'. Econometrica 48 (4): 817-38.

Wilford, A. M. (2017). Polarization, Number of Parties, and Voter Turnout: Explaining Turnout in 26 OECD Countries. Social Science Quarterly, 98(5), 1391-1405. 